\title{
A MATHEMATICAL AND HISTORICAL ANALYSIS AND VERIFICATION OF THE MIRACULOUS NUMBER NINETEEN IN THE NOBLE QUR'AN"')
}

\author{
Yousry Sidrak $^{1}$
}

\begin{abstract}
Among the hundreds of claims of numerical miracles in the Noble Qur'an, the miraculous number 'nineteen' is, probably, the most controversial one. Despite its rejection by many Muslim scholars, there is a widespread support of the claim, as evidenced by the multitude of publications. In his book, 'The Computer Speaks: Allah's Message to the World', published in 1981, Dr Rashad Khalifa claimed that the inclusion of number 'nineteen' in the Qur'an 74: 27-30 is all that Muslims need to understand in order to confirm, beyond any shadow of doubt, that the Noble Qur'an is divine and can only have one author, that is Allah. This research paper presents a mathematical investigation and a balanced evaluation of what Khalifa described as 'Physical facts' in his book. In addition, and since there is a strong correlation between all claims of numerical inimitability and the historicity of the Noble Qur'an, this paper discusses the effect of the historicity of the Qur'an on the claim of a miraculous number 'nineteen'. Mathematical investigation and verification of Dr Khalifa's calculations have been overlooked by scholars in this field, hence the significance of this research paper. In addition, Muslim scholars who have argued against a miraculous number "nineteen" have not, in most cases, presented an academic analysis in support of their arguments, but rather an emotional and personal criticism of the person of Dr Khalifa, especially after he claimed to be an apostle of Allah.
\end{abstract}

Keywords: The Noble Qur'an, Miraculous Number 'Nineteen', Rashad Khalifa, Numerical Inimitability.

() This article was submitted on: 02/08/2016 and accepted for publication on: 04/11/2016.

1 Postal Address: 23 Doreen Rogen Way, South Morang, Victoria, Australia 3752, email: ylsidrak@yahoo.com 


\section{INTRODUCTION}

Muslim scholars have addressed numerous forms of Qur' anic inimitability including, but not limited to, linguistic and rhetorical, biological, metaphysical, numerical, social, psychological and astronomical forms. Thousands of publications related to the subject of Qur'anic inimitability are currently in circulation. These include journal articles, theses, books and conference papers ${ }^{1}$. The word 'inimitability' has been used since not long after the birth of Islam, first by Ibn Hanbal (d. 240/855) ${ }^{2}$. Its use, however, was limited to linguistic and rhetorical inimitability. This has been, and still is, its most popular use as Muslims believe that the Noble Qur' an is inimitable in itself regarding its Arabic language and rhetoric.

Although many claims have been made of the presence of numerical miracles in the Noble Qur'an, there is no doubt that Rashad Khalifa could be rightfully described as the pioneer of numerical inimitability. It was in 1972 that Khalifa announced the discovery of what he described as the miracle of the twentieth century; the miraculous number 'nineteen'. Khalifa claimed that the number 'nineteen' is, directly or indirectly, rooted in the numerical system of the Qur'an; its chapters, verses, letters, ..., etc. This, according to Khalifa, provided all the evidence of the divine origin of Muslims' Holy Book. Moreover, Khalifa delivered numerous lectures on numerical inimitability associated with the number 'nineteen' in a number of countries around the world. In addition, the claim of the miraculous nature of number 'nineteen' has been widely used to call for Islam as many Muslim scholars were dazzled by Khalifa's calculations. Khalifa, however, was later accused of belonging to the Bahä'i faith that glorifies the number 'nineteen' and, in 1988; he claimed to be an apostle of Allah and ended up being killed in his house in the state of Arizona, USA in 1990

There is a lack of serious and academic studies that analyse and critique Khalifa's claims, especially as related to its mathematics. This research paper is an attempt to fill the gap left by other scholars to look closely at what Khalifa called "Physical Facts", and present an analysis, investigation and critique of those "facts" one by one, as well as an investigation of the academic integrity of his mathematical calculations.

In addition, and because all claims of numerical inimitability in general, and a miraculous number 'nineteen' in particular, rely heavily on Qur'an-related numbers; the historicity and reliability of those numbers will be examined when they come up in the

${ }^{1}$ Al-Jayyousī, A. (2005). The efforts exerted in studying inimitability in the old and new times. Paper presented at the Qur'anic Inimitability Conference, Zarqā, Jordan: Zarqā University, p. 1.

2 Ibn-Hanbal, A. (1987). Creed as narrated by Abū Bakr al-Khalāl, edn 1, Dār Katība, Damascus: Abdūl aziz Izzūddīn al-Sirwān, realization), Vol. 1, p. 118. 
relevant physical fact. Qur'an-related numbers include, but are not limited to, number of chapters, number of verses in each chapter, number of words and letters in each verse or chapter, and the order of chapters in the Noble Qur'an.

All Qur'anic verses cited in this research paper are taken from the translation of the Noble Qur'an by Abdullah Y. Ali ${ }^{1}$.

Words, letters... etc. in the Noble Qur'an have been counted with the aid of a universal and widely-used computer program, namely 'Barnamij Ihsa'a Al-Quran AlKarim $^{2}$

\section{LITERATURE REVIEW ON NUMERICAL INIMITABILITY}

Numerical inimitability is the most recent form of Qur'anic scientific inimitability, and it is certainly a contemporary art that is only about 60 years old. It should be differentiated from the statistical counting of the Qur'an, which had its beginnings almost three centuries after the birth of Islam. The latter is simply a statistical counting of Qur'anic verses, chapters, letters and sections and does not address any numerical scientific issues. For more detailed information on statistical counting of the Qur'an, the reader is referred to Ghanem Kaduri (d. 1434/2013) ${ }^{3}$, Abu al Abbas al-Fadl bin Chazan al-Razi (d. 289/902) ${ }^{4}$, Ibn Zanjala (d. 420/1029) $)^{5}$ and Abu Umar al-Dani al-Andalusi (d. $444 / 1052)^{6}$.

Ahmed Shukrī ${ }^{7}$ reported Bedī uzzamān Saīd Nūrsī as the first Muslim scholar to address numerical inimitability.

${ }^{1}$ Ali, A.Y. (2005). The Meaning of the Holy Qur'an. Kuala Lumper, Malaysia: Islamic Book Trust.

2 Kahil. A. (2016). Barnamij Ihsa'a Al-Qur'an Al-Karim. Kahil7.com/ar/index.php/1/16902014-07-03-19-11-02. Version 3.4.

${ }^{3}$ Kaduri, G. (Ed.). (1994). Al-bayān fi' 'add Aỹ al-Qur'ān. Kuwait, Kuwait: Markaz al-Makhtụtāat wa-al-Turath wa-al-Wathä iq.

${ }^{4}$ Razi, A. (2009). Suwar al-Qur'ān wa-āyātuhu wa-hurưfuhu wa-nuzu7uh. Riyadh, Saudi Arabia: Dār Ibn Hazm.

${ }^{5}$ Ibn-Zanjalah, A. (2006). Tanzil al-Qur'ān wa-'adad ayātih wa-ikhtilaf al-nās fih li-AbūZur'ah Majallat Ma'had al-Imām al-Shậtibílil-dirāsāt al-Qur'āniyah(2), pp. 231-295.

${ }^{6}$ Dani, U. (1994). The manifestation in counting the Qur'anic verses, realization in Dr Ghānem Kadūrī l-Hamad, (ed.), book title, edn 1, Kuwait: Manuscripts, Heritage and Documentation Centre.

7 Shukrī, A. (2008). 'Essay on numerical inimitability: a critical study'. Damascus: Dār AlGhawthānī for Qur'anic studies, p. 19. 
The term 'Numerical Inimitability', however, was first introduced by Abd alRazzāq Nawfal in his book, 'Numerical Inimitability of The Qur'an' ${ }^{1}$. Nawfal also made some observations regarding numerical patterns in the Qur'an in previous publications, e.g., 'Islam: Religion and World' 2, where he noted that the words ' الدنيا Dunia ' and ' الآخرة Akhira', are repeated the same number of times in the Qur'anic text, i.e., 115 times each.

In an article titled 'In America, they interpret the Holy Qur'an using computers', the controversial Rashäd Khalifa announced what he described as the miracle of the twentieth century, the numerical inimitability of the number 'nineteen'. Based on his interpretation of The Qur'an 74:30 'Over it are 'nineteen', Khalifa asserted that the number 'nineteen', must be rooted in the numerical system of the Qur'an; its number of chapters, verses, letters... etc.

The existence of number 'nineteen', directly or indirectly, in the Qur'anic text is, as Khalifa stated, the evidence of the divine origin of the Holy Book of Muslims. Moreover, Khalifa delivered numerous lectures on numerical inimitability associated with the number 'nineteen' in a number of countries around the world.

In the introduction to his book, 'The Wonders of the Number and the Enumerated in the Holy Qur'an ${ }^{4}$, Jamil Dibaja stated that the starting point for research on numerical inimitability stems from the findings of Khalifa with respect to the number 'nineteen'. Dïbāja also confirmed Nawfal's findings in regard to the equality in number of many opposing words in the Qur'an, such as 'الملائكةMaläika ' and 'الشياطين Shayātīn', and 'الآخرة' Akhira', as well as many others.

The Shiite author, Labib Baydoun, introduced the topic by pointing to the history of the Qur'an in terms of revelation, order of chapters and verses and compilation ${ }^{5}$. He pointed to the fact that Alī bin Abū Tãlib's version of the Qur'an and that of Uthmān ibn 'Affān differ in the order of chapters. Baydoun supported the conclusions reached by Khalifa in regard to the miraculous number 'nineteen'. As for the letters that represent the

1 Nawfal, A. (1983). Numerical and numeric inimitability of the Qur'an. Beirut: Arabic Book Publishers, p. 10.

${ }^{2}$ Nawfal, A. (1964). Islam: religion and world. Cairo: Dār Alqaomīyah for Distribution.

${ }^{3}$ Khalifa, R. (1972). Fi Amrika bi-al-uqul al-iliktruniyah yufassiron al-Qur'an al-Karim, Akhir Sa'ah.

4 Dïbāja, J. (1999). The wonders of the number and the enumerated in the Holy Qur'an. Beirut: Dār Al-Mahaja al-Baīda' for Publishing and Distribution.

5 Baydoun, L. (1999). Al-I jaz al-adadi fi al-Qur'an al-Karim. Beirut, Lebabnon: Mu'assasat alA'lami lil-Matbu'at. 
openings of some chapters, Baydoun confirmed the findings of Khalifa as to their divine meanings and inimitable numerical connotations, giving many related examples. It is noted, however, that the author rarely provided any references.

One of the books that shed particular light on the importance of the order of chapters and verses is 'The Remarkable Numerical Inimitability Concerning the Order of Verses and Chapters in the Holy Qur'an' by Abdullah Jalghüm ${ }^{1}$. The author stated that the order of chapters and verses is divinely intended to prove the Qur'anic numerical inimitability theorem. He thoroughly discussed many numerical theorems associated with the order of the Qur'anic chapters and verses. Despite the recognition by Jalghüm of the claim of the miraculous 'nineteen' and the inimitability of the openings of some chapters, he was inclined to attribute those findings to Khalifa. The author based his work on the numerical value assigned to each letter of the Arabic alphabet to prove the numerical inimitability of the Holy Qur'an.

Numerical inimitability, on the other hand, does not enjoy the support of many Muslim scholars who deny its very existence. In his 1985 book, 'nineteen' Angels', the author Hussein Nàjī, described numerical inimitability of the Qur'an as a deception orchestrated by the Bahā'i faith ${ }^{2}$. In its totality, Nājī's book is an objective response to Khaliffa's claims and writings, especially Khalifa's book, 'Over it are 'nineteen'. Nājī attributed the origin of the miraculous 'nineteen' to the Bahā'i faith since it sanctifies such numbers. He also provided many examples to show the possibility of extracting selective digits and numbers from the Qur'an that would appear to have a particular pattern, although they have no connection whatsoever with any inimitability.

Ayman al-Mūsāwì has refuted many of the published examples of numerical inimitability and described as invalid the assumptions upon which they are founded ${ }^{3}$. AlMūsāwī also pointed to lack of research methodologies and consistency in respect to the use of derivatives, synonyms, plural and singular forms of the Arabic words. In his book, 'Qur'anic Numerical Inimitability between Reality and Illusion', Fatih Hosni ${ }^{4}$, reported that the majority of numerical inimitability claims are coincidental and occur by chance; therefore, they are not divinely designed. It should be pointed out at this stage that a small number of Muslim scholars have taken a middle path between those who claim and those who deny the presence of numerical inimitability in the Noble Qur'an. Those researchers

${ }^{1}$ Jalghum, A. (2007). Min rawa'i al-i'jaz al-adadi fi tartib al-Qur'an al-Karim. Amman, Jordan: Dar al-Ma'mun lil-Nashr wa-al-Tawzi'.

2 Nagi, H. (1985). Tis'at ashar malikan. Cairo, Egypt: Al-Zahra lil-I'lamal-'Arabi.

${ }^{3}$ Al-Mūsāwī, A. (2001). Testing the Qur'anic numerical inimitability, edn 1, Beirut, Lebanon: Dār al-Hādī for Printing, Publishing and Distribution, p. 29

${ }^{4}$ Hosni, F. (2003). Al-I'jaz al-adadi fi al-Qur'an bayna al-haqiqah wa-al-wahm, Amman, Jordan: Juhaynah lil-Nashr wa-al-Tawzi. 
have set out to establish some guidelines against which the authenticity of each claim of numerical inimitability should be checked individually. Among those scholars are: Khidr $^{1}$, Kahil ${ }^{2}$, Farahat ${ }^{3}$, Dhu-Al-Kifl ${ }^{4}$, Sawab $^{5}$, Al-Rumi $^{6}$ and Awadi ${ }^{7}$.

\section{CLAIMS OF A MIRACULOUS NUMBER 'NINETEEN'}

As stated by Shukri', Rashad Khalifa's book, entitled 'The Computer Speaks: Allah's Message to the World,' is the first mathematical analysis of the miraculous 'number 19' and its associated parallels and links in the Noble Qur'an. Khalifa published few books that address and confirm the presence of numerical miracles in the Noble Qur'an and linked them to contemporary scientific facts.

Khalifa stated that Muslims need not read or study any book but that of Allah, i.e., the Noble Qur'an, in order to see for themselves, and also to show the world, that the Qur'an is divine and can only have one author, and that is Allah. What are the basis upon which Khalifa made those claims? To answer this question, one must consider the interpretation of the Qur'an 74:27-31 "And what will explain to you what Hell-fire is? Naught does it permit to endure, and naught does it leave alone. Darkening and changing the colour of man. Over it are 'nineteen'. And We have set none but angels as Guardians of the Fire; and We have fixed their number only as a trial for Unbelievers, in order that the People of the Book may arrive at certainty, and the Believers may increase in Faith, and that no doubts may be left for the People of the Book and the Believers, and that

${ }^{1}$ Khidr, M. (1998). dawabịt al-i'jaz̄ al-'adadí fí al-Qur'ān al-Karim. Retrieved http://www.almishkat.com/khedher/?p=39

2 Kahil, A. (2007). Al-raqm sab 'ah yashhadu 'alá 'azamat al-Qur'an al-karim. Paper presented at the Al-I'jaz al-'adadi fí al-Qur'ān al-Karim, Dubai, UAE.

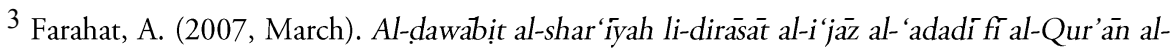
Karim. Paper

presented at the Al-I'jāz al-'adadí fí al-Qur'ān al-Karim, Dubai, UAE. http://sh22y.com/vb/t51380.html

${ }^{4}$ Dhu-Al-Kifl, M. (2008, November ). Al-i 'jaż al-'adadí mafhümuhu wa-dawabituhu. Paper presented at the

International Conference on $\mathrm{Al}-\mathrm{i}^{\text {‘ }} \mathrm{j}$ az al-'adadi fi al-Qur'ān, Rabat, Morocco.

http://www.comijaz.org/detaille livre.php?id_livre $=67$

5 Sawab, S. (2009). Al-I'jaz al-'adadí fi al-Qur'ān al-Karim. The Higher College of the Holy Qur'an, p. 17.

${ }^{6}$ Al-Rumi, F. (2010, March). Dawabịt al-i 'jāz al- 'adadí fí al-Qur'ān al-karím. Paper presented at the International Conference on Al-i 'jaz al-'adadí fi al-Qur'ān, Rabat, Morocco.

7 Awadi, A. (2010). Dawabịt muqtarahah li-ta'sil al-bahth fí al-i'jāz al-'adadí. Retrieved http://www.alukah.net/Social/0/26165/

${ }^{8}$ Shukrī, A. (2008). 'essay on numerical inimitability: a critical study'. Damascus: Dār AlGhawthānī for Qur'anic studies, p. 20. 
those in whose hearts is a disease and the Unbelievers may say, 'What symbol does Allah intend by this?' Thus does Allah leave to stray whom He pleases, and guide whom $\mathrm{He}$ pleases; and none can know the forces of your Lord, except He and this is no other than a warning to mankind"

According to Khalifa, the purpose of the inclusion of number 'nineteen' in verse 30 above is threefold: (1) for the People of the Book, i.e., Jews and Christians, to believe in the divinity of the Qur'an and the authenticity of the religion of Islam; (2) for believers, i.e., Muslims, to increase in faith; and (3) as a testimony to the unbelievers. Dr Khalifa believed that this number and its multiples penetrate the whole text of the Qur'an and represent the binding material of its verses and chapters.

In order to authenticate his beliefs, Khalifa used a computer to analyse the numerical structure of the Qur'an. He then published his results, in the form of physical facts, in his 247-pages book "The Computer Speaks: Allah's Message to the World"1

\subsection{Investigation and Critique of Physical Facts}

In this section, an investigation, analysis and critique of some of Dr Khalifa's physical facts is presented, in order to show the shaky ground of those claims.

- Physical fact 1 (p. 6): The Qur'an is composed of 114 chapters, which is a multiple of 19.

This is only true for the current version of the Qur'an, known as Uthman's or Hafs' Version $^{2}$. Ibn Masoud's Qur'an, however, is composed of 112 chapters $^{3}$ and Ubay bin Ka'b's Qur'an is composed of 116 chapters $^{4}$ (Suyuti, 1996). Neither of these numbers is a multiple of 19.

The last two chapters in Uthman's version of the Qur'an were dropped by Ibn Masoud as he described them as Doa'a, or supplications, hence the smaller number of chapters in Ibn Masoud's Qur'an. On the other hand, Ubay bin Ka'b included in his Qur'an two extra chapters, i.e., al-Hafd and al-Khal'a. al-Hafd reads: "O Allah, we seek your help and ask your forgiveness, and we praise you and we do not disbelieve in you. We separate from and leave who sins against you". Al-Khal'a reads: "O Allah, we worship You and to You we pray and prostrate and to You we run and hasten to serve You. We hope for Your mercy and we fear Your punishment. Your punishment will certainly reach

${ }^{1}$ Khalifa, R. (1981). The Computer Speaks: God's Message to the World. Tucson, USA: Mosque of Tucson.

2 Firuzabadi, M. (1996). Bạsāir ir dhawíal-tamyiz fí lạtả if al-Kitab al- 'Azíz (M. Najjar Ed.). Cairo, Egypt: al-Majlis al-A'lá lil-Shu' un al-Islāmiyah.

3 IbnQasim, A. (1990). Hāshiyat Muqaddimat al-tafsir (2 ed.). Damascus, Syria: Al-Mạtba'ah al-hāshimiyah, p. 1/29.

${ }^{4}$ Suyuti, J. (1996). Al-itqān fi' 'ulūm al-Qur' ān (S. almandub Ed.). Beirut, Lebanon: Dār al-Fīqr, p. $1 / 178$. 
the disbelievers". It should be noted that the variations of the number of chapters in the different versions of the Qur'an can only indicate that this number is not divine.

- Physical fact 2 (p. 7): The first Qur'anic revelation consists of 19 words in the first 5 verses of the Qur'an 96:1-5.

- Physical fact 3 (p. 8): The last Qur'anic revelation consists of 19 words in An-Nasr 110.

Some questions arise here regarding the selective method used by Khalifa to prove his point. In Physical fact 2, no reason is given of selecting only the first 5 verses of the first Qur'anic Revelation, the Qur'an 96:1-5, to show that they consist of 19 words. The lack of academic integrity in this selection of verses becomes even more apparent when one examines Physical fact 3, in which Khalifa considered all, and not part of, the last Quranic Revelation, An-Nasr, 110, in order to find the number 19 in it. On the other hand, according to Noldeke ${ }^{1}$, there is a disagreement among Muslim scholars whether verses 1-5 of the Qur'an 96 are indeed the first revealed verses. According to Khalifa, not only do the first five verses of the Qur'an 96 contain 19 words, but these words also contain 76 letters and this number is also a multiple of 19. Khalifa overlooked the fact that the Qur'an was revealed in seven characters ${ }^{2},{ }^{3}$ and different readings ${ }^{4}$. As a result, some words or letters are sometimes mentioned in one Qur'anic reading and not the other. For example, (وما كنا لنتدي), the Qur'an 7:43, includes the letter (و) 'o', but other

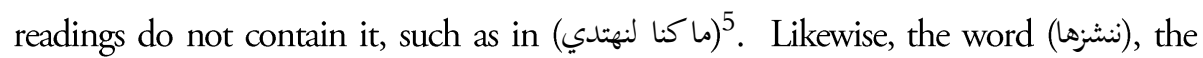
Qur'an 2:259; in one reading and (نشرها) with (ر) ' $r$ ' letter, instead of (j) ' $z$ ' in another reading ${ }^{6}$.

- Physical fact 5 (p. 10): The first chapter revealed, i.e., the Qur'an 96, is found in position 19 from the end of the Qur'an, i.e., if one counts backward.

Despite the fact that there is no logical, theological or mathematical justification for backward counting, the order of Chapters in the Noble Qur'an is a matter of dispute among Muslim scholars.

There are three schools of thought as to the nature and origin of the order of chapters in the current version of the Qur'an.

${ }^{1}$ Noldeke, T. (2008). Tāikh al-Qur'añ. Koln, Germany: Al-Kamel, pp. 67-71.

2 Al-Bukhari, M. (1987). Sahịh al-Bukhārí (3rd ed.). Beirut, Lebanon: Dār ỉbn Kathīr, p. 340.

${ }^{3}$ Muslim, I. (1955). Sahih Muslim. Beirut, Lebanon: Dar al-Da’waa, p. 560.

${ }^{4}$ Al-Qurtubi, M. (2003). Al Jami 'li ahkam al Qur'an. Riyadh, Saudi Arabia: Dār 'Alam alKutub, p. $1 / 45$.

${ }^{5}$ Dani, U. (2007). Jāmi ‘ al-bayān fí al-qirāàt al-sab'. Sharjah, UAE: al-Dirāsāt al-'Ulyā wa-alBaḥth al-'Ilmí, Jāmi'at al-Shäriqah, p. 3/1088.

${ }^{6}$ Ibn-Mujahid, A. (1980). Kitab al-sab 'ah fi al-qira àt (2nd ed.). Cairo,, Egypt: Dār al-Ma'ārif, p. $1 / 189$. 
The first school of thought considers that Qur'anic chapters were arranged by the companions of Prophet Muhammad (p.b.u.h) after his death. This school of thought is embraced by the majority of Muslim scholars ${ }^{1}$, who have deduced this point of view from a wealth of supporting evidence, such as the existence of differences in the order of chapters among the different versions of the Qur'an. So, the Qur'anic version in circulation today, known as Hafs' or Uthman ibn Affan's, Version, differs in its order of Chapters from the one attributed to Ubay ibn Ka'ab and the one attributed to Ibn Masood. It is only the Qur'an according to Ali bin Abi Taleb that had its chapters arranged according to their perspective times of revelations, i.e. Al-Alaq :96, AlMuddaththir :74, Qaf :45, al-Muzzammil :73, Al-Masad :111 and then Al-Takwir :81 and so on till the last of both Meccan and Medinan chapters ${ }^{2}$. This indicates that the different Qur'anic chapters were placed in an order according to each companion's independent reasoning. Had the order been divine, i.e. originated with the Prophet (p.b.u.h), there would have been no differences in the way different chapters are arranged in the different versions of the Qur'an ${ }^{3}$.

The second school of thought teaches that the arrangement of chapters in the Qur'an only partially originated from Prophet Muhammad (p.b.u.h), i.e., he arranged only some chapters while the rest were arranged by the companions according to their own independent reasoning. Chapters arranged by the Prophet (p.b.u.h) were: "The Seven Long chapters ${ }^{4}$, the Al-Moufassal chapters ${ }^{5}$, and the "Al-Hawamim" chapters 6,7 . Among those who support this thought are Ibn Attiya and Abu Jafar ibn al-Zubayr ${ }^{8}$. One, however, could argue that regardless of the place in which those sections of the Qur'an were positioned; the fact still remains that the order of chapters in the Qur'an as a whole did not originate with the Prophet (p.b.u.h). As a result, any claim of numerical inimitability that is based on the order of chapters will fail. The bottom line is that the

${ }^{1}$ Ibn-Hajar, A. (1960). Fath al-bari bi-sharh Sahih al-Bukhari. Beirut, Lebanon: Dar al-Ma'rifah.

${ }^{2}$ Al-Zzarkashi, M. (1972). Alburhan fi ulum al-Qur'an (M. A. Ibrahim Ed). Beirut, Lebanon: Dar al-Ma'rifah.

${ }^{3}$ Zurqani, M. (1996). Manahil al- 'irfān fi 'ulūm al-Qur'ān (1 ed.). Beirut, Lebanon: Dār al-Fikr

4 These are: Al-Baqarah:2, Al Imran:3, Al-Nisa:4, Al-Ma'ida:5, Al-An'am:6 and Al-A'raf :7; they differed regarding whether the seventh chapters was Al-Anfal:8 or Al-Tawbah:9.

${ }^{5}$ These are: Qaf:45, Al-Isra:17, Al-Kahf:18, Maryam:19, Ta-Ha:20, and Al-Anbiya:21.

${ }^{6}$ The chapters that start with the letters $\mathrm{H} \& \mathrm{M}$ (Ha, Mim), such as Ghafir:40, Fussilat:41, AlShura:42, Al-Zukhruf:43, Al-Dukhan:44, and Al-Jathiya:45.

7 Suyuti, J. (1976). Asrar tartib Al-Qur'an (A. Aatta Ed. 1 ed.). Cairo: Dār al-I'tịsām.

8 Zurqani, M. (1996). Manahil al-'irfān fí 'ulüm al-Qur'ān (1 ed.). Beirut, Lebanon: Dār alFikr 
chapters of the Qur'an are not in the order in which they were revealed. i.e., they are not in a chronological order.

The third school of thought teaches that the order of chapters in the entire Qur'an did originate with Prophet Muhammad (p.b.u.h). The strongest evidence for this is based on 'Ijmā' (the consensus) $)^{1}$ and that is the agreement to accept Uthman ibn Affan's version of the Qur'an as the final and authentic copy and to follow the order of chapters arranged therein ${ }^{2}$. Supporters of this school of thought argue that since both scholars and the Muslim community agreed to accept this version and to follow its order, and since the Prophet (p.b.u.h) asserted that 'My community will never agree upon an error' ${ }^{3}$, this can only indicate that Uthman's version has the chapters arranged in the correct order ${ }^{4}$. To adopt this point of view, however, is to admit the uncertainty and the shedding of many doubts on claims of numerical inimitability that are based on the order of chapters in the Qur'an, since the later originated with Muslims' consensus rather than by divine inspiration. A closer look at the first two schools of thought would reveal that the majority of Muslim scholars believed that the Qur'anic chapters were not arranged according to Prophet Muhammad's order, which inevitably invalidates the alleged consensus posited by the third point of view and, consequently, physical fact 5 under consideration.

- Physical fact 6 (p.13): The first chapter revealed, i.e., the Qur'an 96, consists of 19 verses.

The number of verses in each chapter, however, is not divine and did not originate with Prophet Muhammad (p.b.u.h). This is the case not because verses have been deleted or added to the Noble Qur'an, but rather because in some versions of the Qur'an that are currently in circulation in Muslim countries, one verse might split into two, or two verses might combine or join into one verse. There are, indeed, discrepancies in the number of verses in the same chapter among the different versions of the Qur'an currently in circulation. The claim that the Qur'an 96 has 19 verses is only valid in Hafs', or Uthman ibn Affan's, narration of the Qur'an. In the Al-Dawri (الدوري) narration of the Qur'an that is still in circulation, however, the Qur'an 96 has 20 verses, which is not a multiple of 19. The higher number of verses, however, is not a result of the addition of

1

Consensus is an accepted reference among Muslims. It refers to the agreement of all Muslim scholars in a certain era on a religious ruling(Almawardi, 1999).

${ }^{2}$ Nawawi, A. (1972). Sahịh Muslim bi-sharh al-Nawawí(2 ed.). Beirut: Dār Ihya à al-Turāth al'Arabí.

3 Daulabi, M. (2000). Al-kuná wa-al-asmả (N. Faryabi Ed. 1 ed.). Beirut, Lebanon: Dār Ibn Hazm.

${ }^{4}$ Zurqani, M. (1996). Manahil al-'irfān fí 'ulüm al-Qur'ān (1 ed.). Beirut: Dār al-Fikr

5 Al-Basari. A. (2013). The Noble Qur’an, Al-Dawri Narration. Beirut, Lebanon: Dar Ibn Kathir. 
an extra verse, but because verse 15 in the Hafs' narration is split into 2 verses, 15 and 16 , in the Al-Dawri narration. On the other hand, the Qur'an 96 has only 18 verses in BinAmmar (بن عمار) narration ${ }^{1}$. The reason for the lower number of verses in this case is that verses 9 and 10 in Hafs' narration have been combined or joined into one verse, i.e. verse 9, in Bin-Ammar narration. Bin Ammar narration is still in circulation today.

One could conclude, then, that any claim of numerical inimitability that is based on the number of verses in a particular chapter in the Noble Qur'an, is invalid as this number is not divine.

- Physical fact 9 (p. 17): The first word in the Qur'an's opening statement is 'ism' (il), which is repeated 19 times in the entire Qur'an.

The first word in the Qur'an, however, is not 'ism', but 'bism' (بْ̣). The reason that Khalifa declined to use the correct word is, obviously, that the correct word repeats only 3 times in the entire Qur'an, and not 19.

- Physical fact 10 (p. 18-85): The second word in the Qur'an, 'Allah', is repeated 2,698 times, which is a multiple of 19 .

There is no agreement on that number, as the counting depends on the word and its derivatives. The program used in this research paper produces the result of 2699, which is not a multiple of 19 . Kahil, however, pointed to the importance of $2699^{2}$ stating that 2699 is a number that is only divisible by itself making it a reference to the Oneness of Allah. As will be discussed later, however, there is an infinite number of those numbers that are only divisible by themselves, called prime numbers in mathematical sciences. So, there is no uniqueness in the number 2699. It is also interesting to note that when this number is searched in Google in English, one gets 2,698. When searched in Google in Arabic, however, one gets 2,699 and sometimes 2,697, neither is divisible by 19 .

- Physical fact 11 (p. 86): The third word in the Qur'an's opening statement is 'AlRahman' (الرَّمَن.

This assertion is not true, as the term "Al-Rahman", is repeated only 48 times. The reason for the discrepancy is that Khalifa considered the word (للرحمَ) "Lil Rahman", which is repeated 9 times, in his counting. Of course, adding 9 to 48 results in 57.

- Physical fact 12 (p. 88): The fourth word in the Qur'an's opening statement, 'Al-

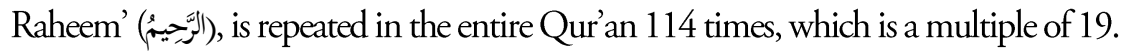

${ }^{1}$ Al-Shami, I. (2009). The Nobe Qur'an, Bin-Ammar Narration. Amman, Jordan: Dar-Al-Fikr.

2 Kahil, A. (2007). Al-raqm sab ah yashhadu 'alá 'azamat al-Qur'an al-karím. Paper presented at the Al-I'jaz al-'adadi fí al-Qur'ān al-Karīm, Dubai, UAE. 
The fact of the matter is that the word (الرَّحِيم) 'Al-Raheem' is repeated 34 times;

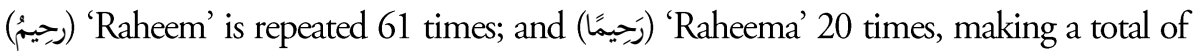
115 times, which is not a multiple of 19. Besides, once again, it is only the word (الرَّحِيم) that should be considered in counting and not any other derivatives of the word.

- Physical fact 14 (p. 96): The difference between the missing Basmalah (بِّنمِ اللَّهِ (الَّمَمْنُ الرَّحِيمِ (In the name of Allah, Most Gracious, Most Merciful) in the Qur'an 9 and the extra Basmalah in the Qur'an 27 is exactly 19.

This assertion is mathematically incorrect. The mathematical difference between 27 and 19 is obtained by subtracting 19 from 27, resulting in 18, and not 19 .

Physical fact 15 (p. 97): The second revelation of the Qur'an, which is the first 9 verses of the Qur'an 68, consists of 38 words, which is a multiple of 19.

In this 'Physical fact', Khalifa assumes that the order of verses in each chapter of the Qur'an is divine, yet there is evidence to prove otherwise. This evidence is reflected in the confusion and hesitation among the companions regarding the order of verses in the Noble Qur'an ${ }^{1}$. The validity of this evidence, however, is contested. If the verses in the Qur'an 68 are not in order, then physical fact 15 fails since the first 9 verses may not be exactly what was 'revealed second'. On the other hand, there is no academic or theological reason for Khalifa to consider the first 9 verses of the Qur'an 68, and not any other number of verses. It was, once again, Khalifa's ungrounded selective method, as in Physical fact 2 above, in order to align numbers to his theory of a miraculous number 'nineteen'.

- Physical fact 19 (p. 103): The theme of the Qur' an is that 'Allah is One'; it has been discovered that ' $19=$ One'.

Khalifa uses what is known as 'al-Jummal' algorithm² to show that the word (واحد) 'one' is equal to 19 . Some claims of numerical inimitability rely on the 'al-Jummal' algorithm that lacks legitimacy. Hosni $^{3}$ questioned the legitimacy of assigning a numerical value to each letter of the Arabic alphabet. On the other hand, the 'al-Jummal' algorithm could be used to infer beliefs that are not accepted by any Muslim and are contradictory to

1 Ibn-Hanbal, A. (1998). Musnad al-imam Ahmed ibn-Hanbal. Cairo, Egypt: Mu'assasat Qurtuba.

2 Jalghum, A. (2007). Min rawä i' al-i 'jāz al- 'adadífítartib al-Qur'ān al-Karim. Amman, Jordan: Dār al-Ma'mūn lil-Nashr wa-al-Tawzí.

${ }^{3}$ Hosni, F. (2003). Al-I'jaz al-adadi fi al-Qur'an bayna al-haqiqah wa-al-wahm. Amman, Jordan: Juhaynah lil-Nashr wa-al-Tawzi' 
Muslims' articles of faith. For example, the 'al-Jummal' algorithm of the word 'شِرك ' 'polytheism' is 19. So, both the words 'وحِ 'polytheism' have the same numerical value, which is 19 .

\subsection{The Claim of Numerical Miracles of Number 'nineteen' in the Qur'anic Chapters that Start with Unknown Letters}

On page 473 of his book, Khalifa stated that the 16 physical facts that have been mentioned thus far are indisputable and are, in themselves, more than sufficient to prove that the Qur'an is not man-made and can only be divine. As has already been shown, Khalifa could not be more wrong about the truthfulness of his physical facts. Moreover, Khalifa asserted that the greater portion of this physical evidence is embedded in the 'mysterious' letters known as 'Quranic initials'. We will examine two of Khalifa's claims regarding the Qur'anic Initials.

- The single-lettered Quranic initial ' $ق$ ' (Q) is found in 2 Chapters, the Qur'an 50 and the Qur'an 42. This letter occurs 57 times, that is a multiple of 19, in both of the two Qur'anic chapters.

In the Qur'an 42, however, the letter (ق)'Q' is not a single-lettered word, but a part of a word (عسق). The Qur'anic initial 'ن' 'N' is found only in the Qur'an 68. It repeats 133 times, which is a multiple of 19. This claim is incorrect, since the letter "ن" repeats only 131 times, which is not a multiple of 19 .

\subsection{Errors in Basic Mathematical Facts}

According to Khalifa, the number 19 contains the first of the digital system that is number 1 , and the last of the digital system, that is number 9. In addition, the number 19 is a unique number as it is only divisible by itself.

The beginning of the digital system, however, is the number zero, not the number 1 . There is also an infinite number of numbers that are divisible only by themselves. Those numbers are called 'Prime Numbers' in Mathematical Sciences. Examples of prime numbers are: 3, 5, 7, 11, 13, 17, 23, 29, 31 ... etc.

It is interesting that, in the translation of the Qur'an that carries his name, Khalifa states that the last two verses of the Qur'an 9, i.e., verses 128 and 129, are not part of the Noble Qur'an ${ }^{1}$. This is because the presence of these two verses disturbs Khalifa's

1 Khalifa, R. (2014). The Qur'an-The Final Testament. Authorized English Version of the Original-Translated by Dr Rashad Khalifa. London, UK: Lulu.com, Appendix 24. 
calculations of the number of repetitions of the word (رَسُولْ ( 'the Messenger'. If these two verses are excluded, this word is repeated 114 times, which is a multiple of 19; while it becomes 115, which is not a multiple of 19, if the two verses are included. Furthermore,

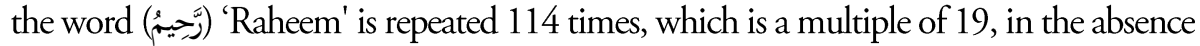
of the two verses, but 115 in their presence. The number 115 is not a multiple of 19 . Likewise, the word (لل) "Allah" is repeated 2,698 times, which is a multiple of 19, excluding the two verses, but 2,699 including them. Additionally, the word (رَبُّ ) 'Ra'ab' is repeated 969 times, which is a multiple of 19 , without the two verses, but 970 with them. Finally, the word (الْعَرَّرَ) 'Al-A'rsh' is repeated 19 times without the two verses, but 20 times with them. Both numbers 970 and 20 are not multiples of 19 .

\subsection{The Use of Unauthorized Mathematical Operations}

Khalifa used the Qur'an 74, al-Muddaththir, which contains 56 verses, to perform some calculations in order to prove the existence of number 19 in the Qur'anic text. Some of those calculations are as follows:

- $56:(5 \times 6)+(6-5)=31$

- 56: $(5 \times 6)-(5+6)=19$.

Khalifa, then, placed the number 19 to the right hand side of the number 31 to get the number 3119. Furthermore,

- 74: $(7 \times 4)+(7-4)=31$

- 74: $(7 \times 4)-(7+4)=17$

Placing 17 to the right hand side of 31 gives the result 3117 . Khalifa then calls people to wonder on this great miracle of his discovery. If 3117 is added to 3119 , the result is 6236, which represents the total number of verses in the entire Qur'an. Needless to say, placing a number next to another is an unauthorized mathematical operation as there is a huge number of possibilities of mixing two numbers together. There is obviously a lack of academic integrity in the way Khalifa performed his calculations.

\section{CONCLUSIONS}

There is no doubt that Dr Rashad Khalifa is a pioneer in the area of numerical inimitability in the Noble Qur'an. The attraction of many Muslim scholars to Khalifa's work stems from the fact that he used modern scientific methods to examine and analyse claims of numerical inimitability, especially those claims of a miraculous number 'nineteen'. This use of modern scientific methods has, probably, added some kind of legitimacy to his work, as few would doubt his theory and conclusions.

A thorough investigation of the claims made by Khalifa as published in his book 'The Computer Speaks: Allah's Message to the World', however, reveals a lack of academic integrity and an apparent weakness in the foundations that he built his calculations upon. 
Two of the foundations used are the divinity of both the order of chapters and the number of verses in each chapter of the Noble Qur'an. A careful study of the historicity of the Noble Qur'an has revealed that none of those foundations did originate with Prophet Muhammad (p.b.u.h), or were divinely inspired.

In addition, Khalifa made grievous, probably intentional, errors in his mathematical calculations; used unauthorised mathematical operations; and used a selective and unfounded method in his counting of letters, words and verses in the Noble Qur'an.

A conclusion could be made that a belief in a miraculous number 'nineteen' lacks academic integrity and ignores some firm facts surrounding the historicity of the writing of the Noble Qur'an.

Today, there is no agreement among Muslim scholars on the validity of numerical inimitability claims, especially that of a miraculous number 'nineteen', as literature that supports it, and those that deny it are in circulation. There is certainly a need for a more academic approach to the issue of Qur'anic numerical inimitability in general, and to a miraculous number 'nineteen' in particular, and this research paper should help interested researchers to determine, at least, their starting point. 


\section{REFERENCES}

Al-Basari, A. (2013). The Noble Qur'an, Al-Dawri Narration. Beirut, Lebanon: Dar Ibn Kathir.

Al-Bukhari, M. (1987). Sahịh al-Bukhārī'(3rd ed.). Beirut, Lebanon: Dār ibn Kathīr.

Ali, A.Y. (2005). The Meaning of the Holy Qur'an. Kuala Lumper, Malaysia: Islamic Book Trust.

Al-Jayyousī, A. M. (2005). 'The efforts exerted in studying inimitability in the old and new times'. Paper presented at the Qur'anic Inimitability Conference, Zarqā, Jordan: Zarqā University.

Al-Mūsāwī, A. (2001). Testing the Qur'anic numerical inimitability, edn 1. Beirut, Lebanon: Dār al-Hādī for Printing, Publishing and Distribution.

Al-Qurtubi, M. (2003). Al Jami 'li ahkam al Qur'an. Riyadh, Saudi Arabia: Dār 'Alam al-Kutub.

Al-Rumi, F. (2010, March). Dawabịt al-i 'jaž al-'adadí fí al-Qur'ān alkarim. Paper presented at the International Conference on $\mathrm{Al}-\mathrm{i}^{\text {' }} \mathrm{jaz}$ al'adadi fí al-Qur' an, Rabat, Morocco.

Al-Shami, I. (2009). The Nobe Qur'an, Bin-Ammar Narration. Amman, Jordan: Dar-Al-Fikr.

Al-Zzarkashi, M. (1972). Alburhan fi ulum al-Qur'an (M. A. Ibrahim Ed). Beirut, Lebanon: Dar al-Ma'rifah.

Awadi, A. (2010). Dawabịt muqtaraḩah li-ta’sil al-baḥth fí al-i'jāz al'adadi. Retrieved http://www.alukah.net/Social/0/26165/

Baydoun, L. (1999). Al-I jaz al-adadi fi al-Qur'an al-Karim. Beirut, Lebabnon: Mu'assasat al-A'lami lil-Matbu'at.

Dani, U. (1994). The manifestation in counting the Qur'anic verses, realization in Dr Ghānem Kadūrī l-Hamad, (ed.), Kuwait: Manuscripts, Heritage and Documentation Centre.

Dani, U. (2007). Jāmi al-bayān fí al-qirāat al-sab'. Sharjah, UAE: alDirāsāt al-'Ulyā wa-al-Bahth al-'Ilmí, Jāmi'at al-Shäriqah.

Daulabi, M. (2000). Al-kuná wa-al-asma’ (N. Faryabi Ed. 1 ed.). Beirut, Lebanon: Dār Ibn Hazm.

Dhu-Al-Kifl, M. (2008, November ). Al-i ‘jaz al-'adadí mafhümuhu wadawabituhu. Paper presented at the International Conference on Ali'jaz al-'adadī fí al-Qur'ān, Rabat, Morocco. http://www.comijaz.org/detaille_livre.php?id_livre=67 
Dībāja, J. (1999). The wonders of the number and the enumerated in the Holy Qur'an. Beirut, Lebanon: Dār Al-Mahaja al-Baīda' for Publishing and Distribution.

Farahat, A. (2007). Al-dawabịt al-shar' 'iyah li-dirāsat al-i jazz al-'adadífíalQur'an al-Karim. Paper presented at the Al-I'jaz al-'adadi fi alQur'ān al-Karim, Dubai, UAE. http://sh22y.com/vb/t51380.html

Firuzabadi, M. (1996). Bạsä ir dhawí al-tamyiz fí lạtä if al-Kitab al-'Aziz (M.

Najjar Ed.). Cairo, Egypt: al-Majlis al-A'lá lil-Shu' un al-Islamiyah.

Hosni, F. (2003). Al-I'jaz al-adadi fi al-Qur'an bayna al-haqiqah wa-al-wahm. Amman, Jordan: Juhaynah lil-Nashr wa-al-Tawzi.

Ibn-Hajar, A. (1960). Fath al-bari bi-sharh Sahih al-Bukhari. Beirut, Lebanon: Dar al-Ma'rifah.

Ibn-Hanbal, A. (1987). Creed as narrated by Abū Bakr al-Khaläl, Dār Katība, Damascus: Abdūl aziz Izzūddīn al-Sirwān, realization.

Ibn-Hanbal, A. (1998). Musnad al-imam Ahmed ibn-Hanbal. Cairo, Egypt: Mu'assasat Qurtuba.

Ibn-Mujahid, A. (1980). Kitab al-sab'ah fi al-qirāàt (2nd ed.). Cairo, Egypt: Dār al-Ma'ärif.

IbnQasim, A. (1990). Hasshiyat Muqaddimat al-tafsir (2 ed.). Damascus, Syria: Al-Mạtba'ah al-hāshimiyah.

Ibn-Zanjalah, A. (2006). Tanzil al-Qur'ān wa-'adad àyatih wa-ikhtiläf al-nās fih li-Abū Zur'ah Majallat Ma'had al-Imām al-Shậibí lil-dirāsàt alQur'aniyah.

Jalghum, A. (2007). Min rawa'i al-i'jaz al-adadi fi tartib al-Qur'an al-

Karim. Amman, Jordan: Dar al-Ma'mun lil-Nashr wa-al-Tawzi'.

Kaduri, G. (Ed.). (1994). Al-bayān fí 'add Ay al-Qur'ān. Kuwait, Kuwait:

Markaz al-Makhtụtāt wa-al-Turāth wa-al-Wathä iq.

Kahil, A. (2007). Al-raqm sab 'ah yashhadu 'ala' 'ązamat al-Qur'ān al-karím.

Paper presented at the Al-I' jaz al-'adadífi al-Qur' ān al-Karim, Dubai, UAE.

Kahil, A. (2016). Barnamij Ihsa'a Al-Qur'an Al-Karim.

Kahil7.com/ar/index.php/1/1690-2014-07-03-19-11-02. Version 3.4.

Khalifa, R. (1972). Fi Amrika bi-al-uqul al-iliktruniyah yufassiron al-Qur'an alKarim, Akhir Sa'ah.

Khalifa, R. (1981). The Computer Speaks: God's Message to the World. Tucson, USA: Mosque of Tucson.

Khalifa, R. (2014). The Qur'an-The Final Testament. Authorized English Version of the Original-Translated by Dr Rashad Khalifa. London, UK: Lulu.com. 
Khidr, M. (1998). dawabịt al-i‘jāz al-‘adadī fí al-Qur’ān al-Karīm. Retrieved http://www.al-mishkat.com/khedher/?p=39

Muslim, I. (1955). Sahih Muslim. Beirut, Lebanon: Dar al-Da’waa.

Nagi, H. (1985). Tis'at ashar malikan. Cairo, Egypt: Al-Zahra lil-I'lamal-'Arabi.

Nawawi, A. (1972). Sahịh Muslim bi-sharh al-Nawawí(2 ed.). Beirut: Dār Ihyya al-Turath al- 'Arabí.

Nawfal, A. (1964). Islam: religion and world. Cairo: Egypt: Dār Alqaomìyah for Distribution.

Nawfal, A. (1983). Numerical and numeric inimitability of the Qur'an. Beirut, Lebanon: Arabic Book Publishers.

Noldeke, T. (2008). Tärikh al-Qur'ān. Koln, Germany: Al-Kamel

Razi, A. (2009). Suwar al-Qur'ān wa-àyatuhu wa-hurưfuhu wa-nuzuluh. Riyadh, Saudi Arabia: Dār Ibn Hazm.

Sawab, S. (2009). Al-I'jaz al-'adadí fí al-Qur'ān al-Karím. The Higher College of the Holy Qur'an.

Shukrī, A. (2008). 'Essay on numerical inimitability: a critical study'. Damascus: Dār Al-Ghawthānī for Qur'anic studies.

Suyuti, J. (1976). Asrar tartib Al-Qur'an (A. Aatta Ed. 1 ed.). Cairo: Dār al-I'tịsām.

Suyuti, J. (1996). Al-itqān fi 'ulum al-Qur'ān (S. almandub Ed.). Beirut, Lebanon: Dār al-Fìkr.

Zurqani, M. (1996). Manahil al- 'irfän fi' 'ulum al-Qur'an (1 ed.). Beirut, Lebanon: Dār al-Fikr. 